\title{
The Math Virtual Reality Game as learning media for 1st-Grade School Students
}

\author{
Mahadhika Putra Relawanto ${ }^{1}$, Erdhi Widyarto ${ }^{2}$, Bernardinus Harnadi ${ }^{3}$ \\ \{mahadhikaputrar@gmail.com ${ }^{1}$, erdhi@unika.ac.id ${ }^{2}$, b_harnadi@yahoo.com ${ }^{3}$ \} \\ Information System department, Soegijapranata Catholic University, Jl. Pawiyatan Luhur IV No.1, \\ Bendan Dhuwur, Tinjomoyo, Banyumanik, Kota Semarang, Jawa Tengah 50235 223
}

\begin{abstract}
. most students have difficulty in learning math therefore many methods developed to help students to learn math. many methods develope like the use of props, animation, cartoons, and games. However, some of the methods used are still less evocative of students to be able to follow the lesson with a sense of fun and encouragement to follow the lesson. Virtual Reality (VR) is a technology that can simulate a real environment in computer and the user can interact in the environment. In this study using Game VR as a learning mathematics in 1st-grade primary school students and see the impact of this model on the students in learning mathematics, especially addition and subtraction. the result is the learning math method model with VR.
\end{abstract}

Keywords: 1st-grade school students, game, math, virtual reality.

\section{Introduction}

Today mathematics is a subject that is difficult to understand for students. Turmudi argues that many years mathematics has been attempted to be mastered by students well by educational experts and mathematics education experts, but the results still show that not many students in each class like the math [1]. The same opinion is expressed by Abdurrahman that of various fields taught in schools mathematics is considered the most difficult by the students [2], for the reason that the mathematical concepts which are poorly understood and the limitations of mathematical props used by teachers in delivering learning materials. Sudono explains that props have a function to explain a particular learning material so that students can build their own experience and knowledge [3].

Learning mathematics is really not just learning numbers, numbers, and formulas. The concept of learning mathematics can be applied in everyday life not merely learning something abstract, imaginary and imaginary. To connect the concepts learned with the application in everyday life, it requires a tool or media that is a representation of the concepts learned in everyday life. It aims to facilitate learners in understanding the concepts in learning mathematics so that it is no longer abstract, imaginary and imaginary. Learning with the realization of mathematical concepts is called realistic mathematics learning [4].

The children aged 7 - 11 years are at the concrete operational stage, so the difficulty in this age child is in thinking abstractly. It is necessary for children of that age to take learning to the real world. While Virtual Reality (VR) is a technology that can simulate the real environment in the computer and the user can interact within the environment [5].

ICCSET 2018, October 25-26, Kudus, Indonesia

Copyright (C) 2018 EAI

DOI 10.4108/eai.24-10-2018.2280548 
Ofcom's 2014 annual report explains that $62 \%$ of 5 to 15 -year-olds uses mobile devices, up $20 \%$ from the previous year. The data indicate that tablets and smartphones are an attraction for children [6]. Supported by a Tempo magazine survey report which explains that children now spend most of their day in a week sitting on chairs while playing outdoors (outdoor activities) for only 2.5 hours per day [7]. The activities of sitting in the chair are spent playing games or watching television. On the other hand, with the development of children's technology is presented about the complete gadget facilities so they are more interested in playing games or social media. From the current conditions, there are efforts to take advantage of the development of information and communication technology as an educational tool, especially in the field of mathematics lessons. Technology-Enhanced Learning (TEL) promotes new practices for education, new communication and new ways of communication [8]. On the other hand, many interests emerge in using games as a medium of learning. Playing games means learning something, at least learning the content and dynamics of the game.

Game VR appeals to primary school students because VR has not been as popular as mobile games. Something new then will make the user interested, especially for elementary school children where a great sense of curiosity. With VR games, players will be brought into the 3D VR world.

\section{Literature Review}

\subsection{Learning media}

One important process in learning is learning media because it is a means to display information [9]. According to Edgar Dale's learning cone in figure 1, the best and most effective results in learning are using simulated media or using a model to gain experience because they will remember $90 \%$ of what has been done and the results obtained are the ability to analyze, design, create and evaluate.

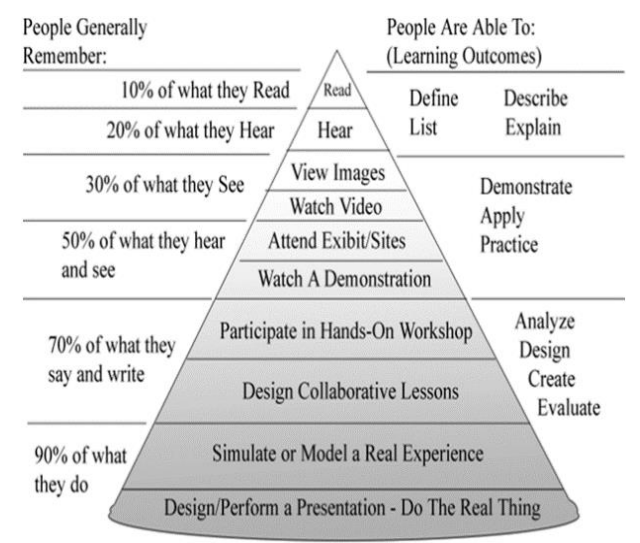

Fig. 1. Conical media learning edgar dale. 
By looking at current technological developments and the level of children's preference for playing tablets and smartphones, the game can be used effectively for learning. The game is a learning medium that contains interesting images and sounds. Images and sounds that are interesting besides that there have interactions between players with the game. this will provide fun, for the reason that it can be used effectively for learning.

\subsection{Education game}

Games can also be interpreted as activities that are usually done for fun and can also be used as learning aids. The game is an interactive activity that can be performed by players where players follow rules and limit game behavior [10]. Education is a process where a person determines the identity and can produce action or behavior for himself, games that have educational content are better known as educational games. Educational games aim to help children's learning interest in learning.

Educational games are games in the digital form designed to help education or support teaching and learning, using new technologies of interactive multimedia technology. This educational media game has several conditions that must be met, like :

a. The content of the game must be educated to the player or the user.

b. Make players can think quickly and precisely.

c. The music in the game allows players to feel the senses in the game.

d. The display must be interesting so that players do not feel bored quickly with the game.

\subsection{Virtual reality technology}

Virtual reality technology enables one to simulate a real object by using a computer generating a three-dimensional atmosphere that makes the user as if physically involved. The virtual reality works as follows: a user sees a pseudo-world, which is actually a dynamic image; then, through a speaker or headphone device, the user hears a realistic sound; by the headset, glove and walker, each user movement will be monitored by a system that will give the appropriate reaction so that the user feels in a real situation, both physically and psychologically.

Virtual Reality Elements [11] :

a. The virtual world, the content of the media provided comes in the form of scenarios or scripts. In this element, users will experience with the virtual world.

b. Immersion, the existing sensation in an environment. Immersion is divided into two types: mental immersion and physical immersion.

c. Sensory feedback, information that is displayed to the user's senses about the virtual world, sensory feedback can be visual, audio or touch.

d. Interactivity, the virtual world that response to user action in real time 


\section{Research Methodology}

\subsection{Data Collection Methods}

The research data was collected by distributing questionnaires as many as 30 students of 1stgrade primary school with age 7-8 years and domiciled in Semarang City. The purpose of data collection is to know the success of VR mathematical games that have been made, how make the students happy and motivated to learn mathematics

\subsection{Flow chart game}

Figure 2 shows the flowchart of math VR games.

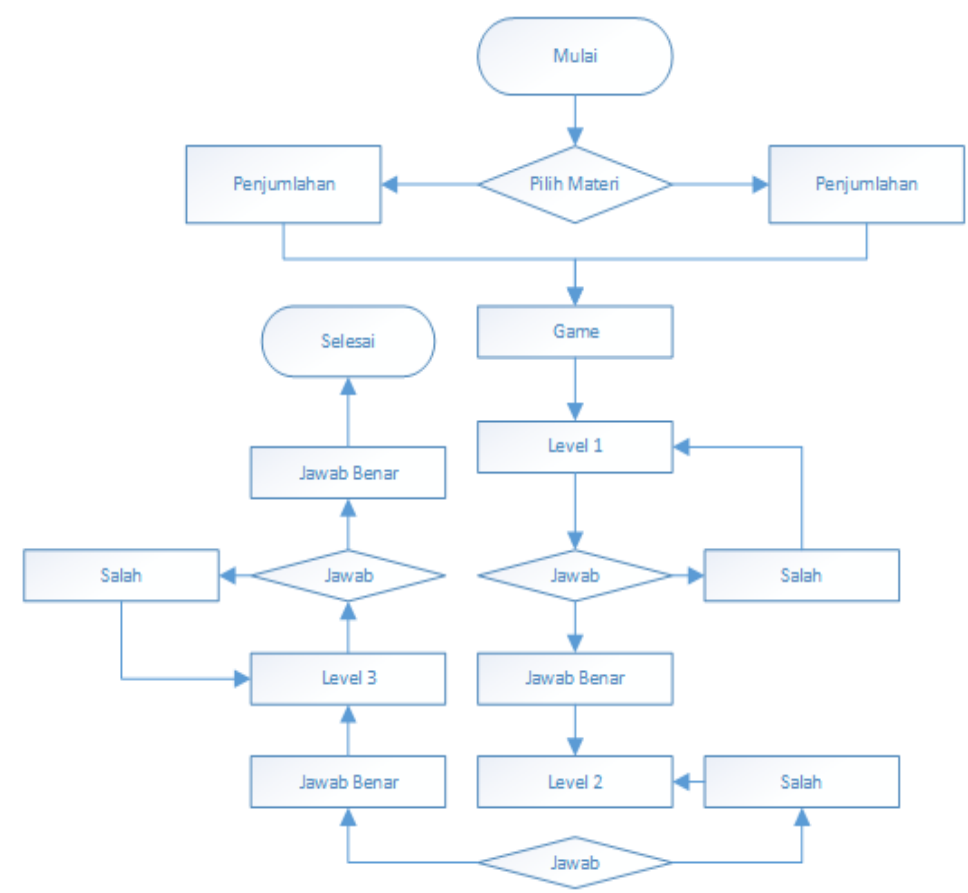

Fig. 2. Flow chart math vr game.

\section{Results And Discussion}

\subsection{Game design}

The "LEARNING MATH VR" game is an educational game has designed the lego land theme and the giving of sound to support the game. The purpose of the use of the lego land theme and the addition of sound is to has the attention for students to play the game. This game has made with Unity engine and Blender software to create 3D assets and made to play like in the real world, and this game played on the Android platform. In this game design has the challenge for 
players, like given limited time to answer questions from several levels provided. the question like addition and subtract. When the player has answered correctly, the player will be rewarded that the player can explore the land of game.

\subsection{Game view}

Figure 3 shows 3D graphics game view with the lego land theme.

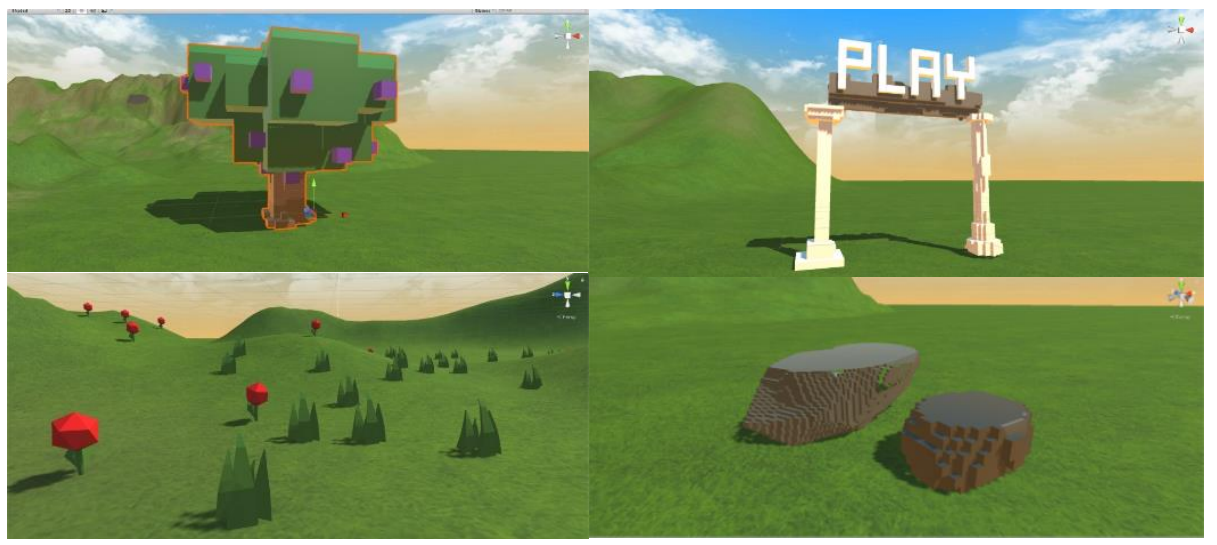

Fig. 3. Lego land theme's.

Figure 4 shows the VR game display like figure 4.1 starts the game, figure 4.2 math gameplay , 4.3 shows limited time, and 4.4 for the scoring.

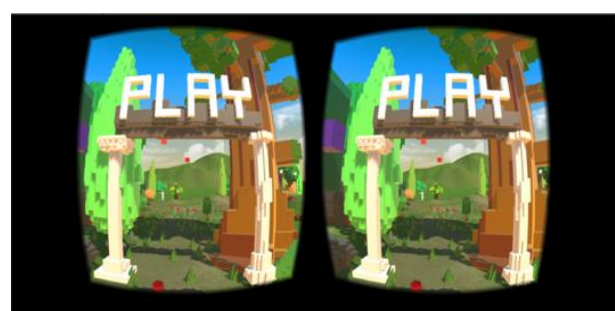

(4.1)

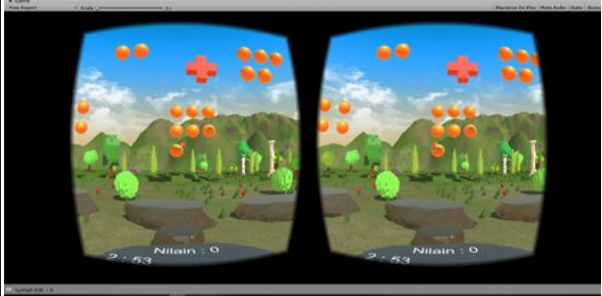

(4.2)

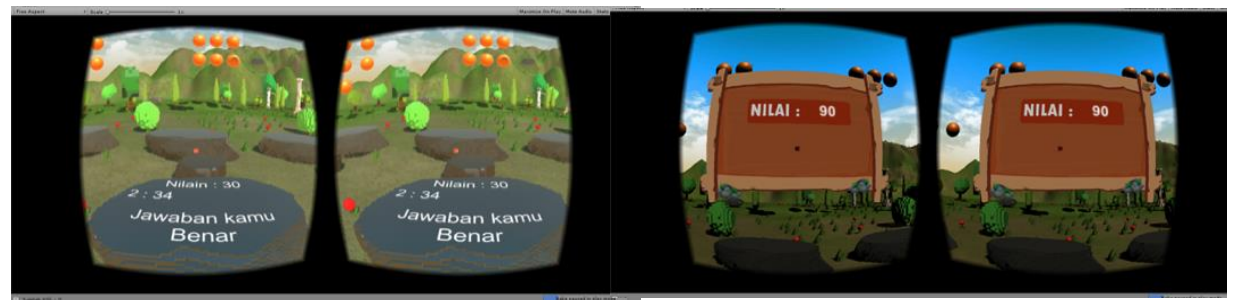

(4.3)

$(4.4)$

Fig. 4. Math gameplay. 


\section{Game Result}

The game has been tested with 30 children to see the interest and understanding of learning math with the game. the result is shown in figure 5 :

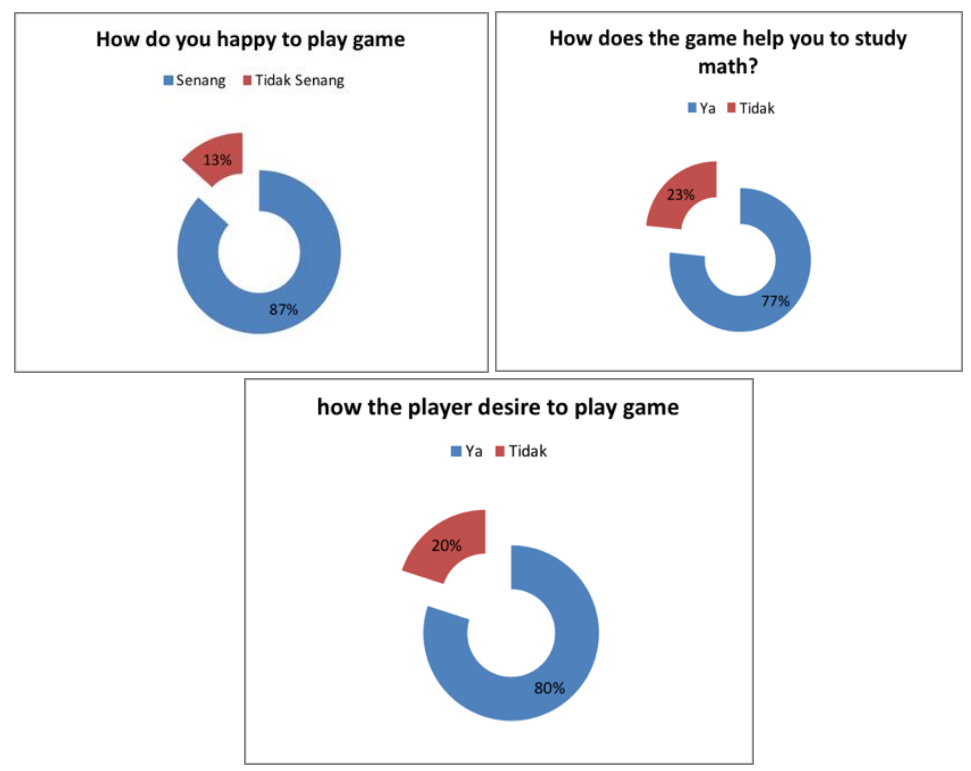

Fig. 5. the result of the game tested.

\section{Conclusion}

a. VR makes players interact like in the real world so that players, especially young children easier to understand the lessons of math VR games.

b. The use of the theme of lego land and interactive sound makes the player more interested and happy in playing math VR games.

\section{References}

[1] Turmudi, Landasan Filsafat dan Teori Pembelajaran matematika (berparagdima Exploratif dan Investigatif). Jakarta: Leuser Cipta Wijaya, 2008.

[2] Mulyono Abdurrahman, Pendidikan bagi Anak Berkesulitan Belajar. Jakarta: Rineka Cipta, 2003.

[3] A. Sudono, "Sumber Belajar dan Alat Permainan untuk Pendidikan Usia Dini." Grasindo, Jakarta, 2010.

[4] "Belajar Matematika Mudah dan Menyenangkan." [Online]. Available: http://www.sekolahdasar.net/2014/12/belajar-matematika-mudah-dan-menyenangkan.html. 
[5] V. R. Society, "What Is Virtual Reality.” Virtual Reality Society, 2017.

[6] Ofcom, Children and Parents : Media Use and Attitudes Report. London: Ofcom, 2014.

[7] Pertiwi and Nugroho, "Measuring the games influence on improving English Proficiencyistem," J. Inf. Syst., 2014.

[8] Ponticorvo, Michela, D. Ferdinando, and Andrea, "Bio-inspired Computational Algorithms in Educational and Serious Games: Some Examples," in Proceedings of 11th European Conference on Technology Enhanced Learning, EC-TEL, 2016, pp. 637-639.

[9] Vasudevamurt, Vinay Bhargav, and A. Uskov, "Serious Game Engines : Analysis and Applications," in Proceeding of 2015 IEEE International Conference on Electro/Information Technology (EIT), 2015, pp. $440-445$.

[10] W. Wibisono and Lies Yulianto, "Perancangan Game Edukasi Untuk Media Pembelajaran Pada Sekolah Menengah Pertama Persatuan Guru Republik Indonesia Gondang Kecamatan Nawangan Kabupaten Pacitan," Speed, vol. 2, no. 2, 2010.

[11] O. Bimber and R. Raskar, Spatial Augmented Reality Merging Real and Virtual Worlds. SpatialAR.com 6, 2005. 